\title{
UMA PROPOSTA DIDÁTICA: A INSERÇÃO DO GÊNERO MICROCONTO EM SALA DE AULA POR MEIO DO APARELHO CELULAR $^{1}$
}

Maria Natália dos Santos Silva, Universidade Federal de Campina Grande (UFCG) Nathalyapb2008@gmail.com

Karla Késsya de Souza Campos, Universidade Federal de Campina Grande (UFCG) Karlaksousa15@hotmail.com.br Abdoral Inácio da Silva, Universidade federal de Campina Grande (UFCG)

Abdoral.silva@bol.com.br

\section{RESUMO}

Procuramos auxiliar o professor em sala de aula no que tange o processo de ensino e aprendizagem da leitura, compreensão e escrita, a partir do trabalho com microcontos. Para tanto utilizaremos o livro virtual Dois palitos, de Samir Mesquita, visando em um primeiro momento o uso do celular no ambiente escolar de forma didática, associando assim o uso da tecnologia ao trabalho com o gênero, tendo em vista que Dois palitos pode ser facilmente acessado na internet por meio do aparelho celular. Ressaltando que o celular pode ser para o homem muito mais do que um simples atrativo. Fundamentando-nos, pois, nos estudos dos Gêneros textuais: definição e funcionalidade (2002), de Luiz Antônio Marcuschi; Gêneros textuais: configuração, dinamicidade e circulação (2005), de Luiz Antônio Marcuschi; Gêneros textuais emergentes no contexto da tecnologia digital*(2010), de Luiz Antônio Marcuschi; Gênero, Agência e Escrita (2010), de Bazerman; e A onda dos microcontos (2010), de Carlos Seabra. Com base nesse aparato estaremos contribuindo de forma educativa não só para o ensino de Língua portuguesa, como também para a formação crítica e social do cidadão enquanto ao uso da tecnologia de modo consciente e produtivo.

Palavras- chave: Microcontos; Gêneros textuais; Tecnologia; Ensino e aprendizagem.

Abstract

\footnotetext{
${ }^{1} O$ presente trabalho (não) contou com apoio financeiro de nenhuma natureza para sua realização.
} 
We seek to assist the teacher in the classroom in the teaching and learning process of reading, comprehension and writing, from the work with the flash fictions. To do so, we will use the virtual book "DoisPalitos", by Samir Mesquita, aiming, at first, to use the cell phone in the school environment in a didactic way, thus associating the use of technology to work with the genre, considering that "DoisPalitos" can be easily accessed on the internet through the mobile device. Emphasizing that the cell phone can be for man much more than a simple attraction. Based on the studies of the Gênerostextuais: definição e funcionalidade(2002), by LuizAntônio Marcuschi; Gênerostextuais: configuração, dinamicidade e circulação(2005), by LuizAntônio Marcuschi; Gênerostextuaisemergentes no contexto da tecnologia digital (2010), by LuizAntônio Marcuschi; Genre, Agency and Writing (2010), by Bozerman; and A onda dos microcontos(2010), by Carlos Seabra. Based on this apparatus, we will be contributing in an educational way, not only to the teaching of Portuguese language, but also to the critical andsocial formation of the citizen regarding to the use of technology in a conscious and productive way.

Keywords: Flash fictions. Textual genres. Technology. Teaching and learning.

\section{Resumen}

Buscamos auxiliar al profesor en el aula en lo que se refiere al proceso de enseñanza y aprendizaje de la lectura, comprensión y escritura, a partir del trabajo con microcontos. Para ello utilizaremos el libro virtual Dos palillos, de Samir Mesquita, visando en un primer momento el uso del celular en el ambiente escolar de forma didáctica, asociando así el uso de la tecnología al trabajo con el género, teniendo en cuenta que Dos palillos pueden ser fácilmente Que se accede a Internet a través del dispositivo móvil. Resaltando que el celular puede ser para el hombre mucho más que un simple atractivo. Fundamentándonos, pues, en los estudios de los géneros textuales: definición y funcionalidad (2002), de Luiz Antônio Marcuschi; Géneros textuales: configuración, dinamicidad y circulación (2005), de Luiz Antônio Marcuschi; Géneros textuales emergentes en el contexto de la tecnología digital * (2010), de Luiz Antônio Marcuschi; Género, Agencia y Escritura (2010), de Bazerman; Y la onda de los microcontos (2010), de Carlos Seabra. Con base en ese aparato estaremos contribuyendo de forma educativa no sólo para la enseñanza de Lengua portuguesa, sino 
también para la formación crítica y social del ciudadano en cuanto al uso de la tecnología de modo consciente y productivo.

Palabras clave: Microcontos; Géneros textuales; Tecnología; Enseñanza y aprendizaje

INTRODUÇÃO:

O presente trabalho abordará de forma sistemática o gênero microconto, também conhecido como miniconto ou nanoconto. Este gênero, embora não seja considerado como gênero literário, será apresentado como uma ferramenta de grande importância no processo ensino-aprendizagem na sala de aula. A partir dessa produção, o professor terá uma base para trabalhar a leitura, escrita e interpretação textual com seus alunos, utilizando um recurso de fácil acesso, os microcontos, que podem ser encontrados facilmente no aparelho celular.

A análise em questão está fundamentada na teoria do gênero textual e gêneros digitais. Os gêneros são de grande relevância, através deles é possível ter conhecimento das formas de interação existentes na sociedade. Nessa perspectiva, os gêneros são múltiplos, pois

Gêneros não são apenas formas. Gêneros são formas de vida, modos de ser são frames para a ação social. São ambientes para aprendizagem. São ambientes para a aprendizagem são os lugares onde o sentido é construído. Os gêneros moldam os pensamentos que formamos e as comunicações através dos quais interagimos. Gêneros são os lugares familiares para onde nos dirigimos para criar ações comunicativas, inteligíveis uns com os outros e são modelos que utilizamos para explorar o não-familiar. (BAZERMAN, 2011, p.23)

Os gêneros por estarem imbuídos nas práticas sociais, devem ser analisados na sala de aula. É bem verdade, que a nossa realidade escolar brasileira deixa a desejar no quesito leitura e produção, esse problema pode ser ocasionado por desinteresse dos alunos, que se limitam a ler, apenas o que está sendo exposto nas redes sociais, ou pela falta de preparo dos professores em estimular de forma dinâmica a prática da leitura e escrita ou por outros motivos. Para isso 
devemos incitar nossos alunos por meio de alternativas que chamem a atenção, uma nova maneira seria a inserção dos microcontos em sala de aula, pois como afirma Seabra (2010), "Micronarrativa tem ingredientes do nosso tempo, como a velocidade e a condensação, a veiculação em celulares e painéis eletrônicos." Ou seja, estaremos levando para a sala de aula aquilo que diz respeito ao nosso cotidiano, a nossa vida social, por meio de um veículo, o celular, que é visto pelo professor muitas vezes como um empecilho e/ou inimigo do livro didático.

Diante ante disso, propomos uma renovação do trabalho com os gêneros. Este trabalho tem como corpus o livro online de microcontos: Dois palitos, de Samir Mesquita, que reúne 50 microcontos que estão contidos dentro de uma caixa de fósforos, ou seja, proporciona uma leitura rápida e dinâmica. Sendo assim ao utilizar os microcontos o professor irá apresentar para os alunos uma nova configuração textual, já que ao ler Dois palitos o aluno fará a leitura utilizando a internet, através do aparelho celular e irá interagir com esse gênero, pois o palito ao ser selecionado começa a queimar e dá apenas alguns minutos para que o leitor leia o conto e sozinho ele se apaga, para que outro palito seja riscado, simultaneamente outro conto seja lido.

É necessário pensar nessa prática associada ao uso do celular, ele será de grande ajuda para essa realização pedagógica. O celular é um objeto que grande parte dos alunos do Ensino Fundamental II possuem, ele tem sido utilizado de forma equivocada, pois na sala de aula a atenção dos alunos é canalizada para ele, nos momentos inoportunos. Se pensarmos em uma atividade em que o celular será utilizado, isso poderá despertar interesse, pois eles irão fazer de um objeto de uso apenas comunicativo, para um recurso material que irá ajudá-los no aperfeiçoamento da leitura, consequentemente na produção da escrita e práticas de construção de sentido.

\section{DESENVOLVIMENTO:}

É perceptível que os gêneros textuais tornaram-se ao longo dos anos referência para o ensino da Língua portuguesa, isso se deve ao fato destes estarem inseridos tanto na nossa vida diária quanto nas nossas práticas sociais comunicativas mais diversas. Atentando-nos também para a variedade dos gêneros que permeiam mais variados ambientes, assim 
Tendo-se em vista que o gênero é essencialmente flexível e variável, tal como o seu componente crucial, a linguagem. Pois assim como a língua vária, também os gêneros variam, adaptando-se, renovando-se e multiplicando-se. (MARCUSCHI, 2005, P. 18)

É por meio dessa flexibilidade, de se permitir uma nova moldagem, que os gêneros tendem a se multiplicarem ainda mais, tanto é assim que se tornou comum nos dias de hoje ouvirmos expressões como e-mail, bate-papo virtual (chat), aula-chat, lista de discussão, blog, editoriais, artigos de fundo, notícias, telefonemas, reportagens ao vivo e muitos outros. Essas expressões nada mais são do que "novos gêneros" que emergem de outros anteriores. Esse surgimento se dá evidentemente a partir da necessidade comunicativa, atrelada aos novos suportes tecnológicos, tais como Jornal, rádio, revista, televisão e o aparelho celular.

Entretanto, para além dos suportes tecnológicos têm-se as tecnologias digitais, tais como computador e o celular, esse último acabou tornando-se o mais presente no ambiente escolar e de essencial importância nas relações comunicativas. As pessoas encontram-se "interligadas" a esse aparelho de tal modo que chegam a esquecer de que para além dele existe vida social, assim como afirma Marcuschi (2010):

O impacto das tecnologias digitais na vida contemporânea está apenas se fazendo sentir, mas já mostrou com força suficiente que tem enorme poder tanto para construir quanto para devastar. Seguramente, uma criança, um jovem ou adulto, viciados na internet, sofrerão sequelas nada irrelevantes. (MARCUSCHI, 2010, p. 16)

A utilização da internet por meio do celular tornou-se comum no nosso dia a dia, mas sabemos que a maioria das pessoas não faz o uso dessas ferramentas de forma adequada, elas restringem as inúmeras possibilidades de se utilizar o aparelho celular e a internet, em detrimento dos seus usos apenas para "bater papo" ou se expor virtualmente por meio do facebook, Whatsapp e/ou via e-mail, o que de certa forma não contribui nem para seu 
desenvolvimento intelectual, nem para a sua formação enquanto cidadãos críticos e participativos em uma sociedade.

No entanto, nós professores podemos e devemos fazer com que nosso alunado tome consciência de que as novas tecnologias digitais, em especial o aparelho celular, pode servir não só para bater papo e postar fotos nas redes sociais, mas também para a aprendizagem educacional em sua forma mais ampla, que é a de torná-los pessoas críticas e ativas, capazes de opinar socialmente, exercendo assim o seu papel de cidadão. Mas de que modo podemos fazer isso? Como podemos chamar a atenção do nosso aluno para esse tipo de aprendizagem?

São inúmeras as possibilidades para se trabalhar a leitura, a compreensão e consequentemente a escrita em sala, entre elas está a utilização dos microcontos, de Samir Mesquita, facilmente encontrados na internet, podendo até mesmo ser acessados por meio do celular.

Em meio a uma sociedade capitalista e imediatista, tudo é programado para ser consumido rapidamente, por não haver tempo, estamos na era do "fastfood", isso implica que não há mais interesse no que demanda muitas horas, até porque a frase que rege é "tempo é dinheiro." Sendo assim os microcontos surgem nesse contexto de brevidades. O homem com o decorrer do tempo muda seu contexto social, muda-se e por consequência modifica os gêneros literários, podemos perceber essa realidade, na produção dos microcontos, que embora derivem dos contos que é um gênero mais antigo, contém um aspecto inusitado, o fato de ser micro e de estar inserido no mundo virtual de forma interativa na internet. Trata-se, portanto de pequenas leituras e grandes reflexões, porém em um curto espaço de tempo.

Os microcontos possibilitam a oportunidade dos alunos se deleitarem em uma leitura que requer pouco tempo, mas não deixa de causar seus efeitos positivos. Já que é notório o pouco interesse pela leitura, os alunos podem se interessar por uma leitura que não passa de uma linha. A concisão é uma das vantagens deste gênero, pois a atividade de leitura pode ser praticada, a fim de se trabalhar o seu aperfeiçoamento e, por conseguinte a construção de sentidos. Um benefício presente ao trabalhar este gênero é a presença da intertextualidade, elemento importante, conforme afirma Bazerman (2006):

A intertextualidade da sala de aula se amplia à medida que estudantes e professores trazem outros textos de fora para a leitura, 
fazem menção a outros cursos e iniciam discussões a partir de assuntos tratados nos jornais ou em documentários televisivos. (BAZERMAN, 2006, p. 97)

Ao se trabalhar com uma nova configuração textual, o professor deverá se reformular e se programar minuciosamente para que sua prática possa ter o efeito esperado, sugerimos assim uma proposta de sequência didática em que o professor pode utilizar como ferramenta de ensino os microcontos.

Uma pequena, mas relevante ferramenta no ensino da leitura, escrita e construção de sentidos: Gênero microcontos

A proposta didática está organizada em momentos. Está ancorada nas teorias desenvolvidas por Bazerman (2011), na sua obra: Gênero, Agência e Escrita; Marcuschi e Xavier no livro: Hipertexto e gêneros digitais novas formas de construção de sentido. Esse percurso didático objetivo pretende trabalhar com os microcontos no Ensino Fundamental II, série $9^{\circ}$ ano. Este gênero será uma ferramenta para as atividades de aperfeiçoamento da leitura, desenvolvimento da escrita e construção de sentidos. Está suscetível a mudanças de acordo com o interesse do professor e seus anseios para desenvolver a atividade na sala de aula. O livro online Dois palitos, do autor Samir Mesquita será o recurso base para essas atividades.

(Primeiro momento)

O professor fará uma sondagem a partir da pergunta: $\mathrm{O}$ que vocês conhecem por microcontos? Ao obter as respostas, ele automaticamente terá uma noção de qual será seu ponto de partida. Poderá falar de forma sucinta a definição do gênero microconto, sua origem e relacionar os novos dados fornecidos para os alunos, com os conhecimentos que eles transmitiram.

(segundo momento)

Neste momento é necessário que o professor incite um debate na sala, cujo tema será: O uso do celular nos dias atuais, ao término, ele poderá mostrar para eles, que esse objeto pode ser de grande proveito, desde que seja usado para acréscimo de conhecimento. É neste momento que o professor irá propor aos alunos que pesquisem na internet os microcontos de 
Samir Mesquita, será indicado o livro online Dois palitos, por meio deles os alunos poderão fazer leituras individuais inicialmente, em seguida leituras coletivas.

(terceiro momento)

Iniciar-se-á com a leitura coletiva dos microcontos e simultaneamente a construção de sentidos. O professor deverá questionar os alunos sobre a concisão, a brevidade e a riqueza de intertextualidade presentes neste gênero. Em seguida o professor instigará os alunos a lerem os que mais chamaram a atenção deles, e posteriormente comentarem suas impressões sobre a existência desse gênero, cuja competência de criação está baseada em ser sucinto e objetivo.

(quarto momento)

Será de grande relevância que o professor convoque os alunos a redigirem seus próprios microcontos. A priori, relembrará os elementos necessários para sua produção e em seguida irá instigá-los a escreverem suas produções. Ao terminarem de produzir, o professor motivará os alunos a lerem o que escreveram compartilharem com os colegas de sala, para que de forma coletiva, os sentidos das produções possam ser construídos.

\section{CONSIDERAÇÕES FINAIS:}

A proposta didática para se trabalhar com os microcontos foi elaborada para ser um auxílio ao professor que tenha por anseio associar tecnologia à educação na sala de aula. Este gênero é de grande relevância e sendo usado de forma eficiente é capaz de produzir excelentes efeitos na dicotomia ensino-aprendizagem. Este trabalho é apenas uma das várias propostas para se trabalhar com os microcontos, e pode ser reformulado conforme deseje o professor.

\section{REFERÊNCIAS BIBLIOGRAFICAS}

BAZERMAN, Charles. Intertextualidade: como os textos se apoiam em outros textos. In: BAZERMAN, C; HOFFNAGEL, J, C; DIONÍSIO, A, P. (org). Gênero, agência e escrita. São Paulo: Cortez, 2006, p. 87-103. 
MARCUSCHI, Luiz Antônio. Gêneros Textuais: definição e funcionalidade. In: DIONÍSIO, A, P; MACHADO, A R; BEZERRA, M, A. (org). Gêneros textuais \& ensino. 2. ed. Rio de Janeiro: Lucerna, 2002, p. 19-36.

MARCUSCHI, Luiz Antônio. Gêneros Textuais: configuração, dinamicidade e circulação.In: KARWOSKI, A, M; GAYDECZA, B; BRIITO, K, S. (org). Gêneros Textuais: reflexões e ensino. Palmas e União Vitória, PR: Kaygangue, 2005, p. 17-33.

MARCUSCHI, Luiz Antônio. Gêneros textuais emergentes no contexto da tecnologia digital. In: MARCUSCHI, L, A; XAVIER, A, C. (org). Hipertexto e gêneros digitais: novas formas de construção de sentido. 3. ed. São Paulo: Cortez, 2010, p. 15-81.

MESQUITA, Samir. Dois Palitos. Disponível em: <http://www.samirmesquita.com.br/doispalitos.html > Acesso em: 10 de Agosto, 2017.

SEABRA, Carlos. A onda dos microcontos. Revista Língua portuguesa, Brasil, Abril, 2010. Disponível em: $<$ https://www.escrevendoofuturo.org.br/conteudo/biblioteca/nossaspublicacoes/revista/artigos/artigo/1013/a-onda-dos-microcontos $>$ Acesso em: 17 de Agosto, 2017. 